Nota científica

(Short communication)

\title{
PATHOGENIC ACTIVITY OF ISARIA SPP. FOR CONTROL OF DACTYLOPIUS OPUNTIAE (HEMIPTERA: DACTYLOPIIDEAE) AND THE EFFECTS OF SELECTED INSECTICIDES
}

\author{
ACTIVIDAD PATOGÉNICA DE ISARIA SPP. PARA EL CONTROL DE DACTYLOPIUS \\ OPUNTIAE (HEMIPTERA: DACTYLOPIIDEAE) Y LOS EFECTOS DE ALGUNOS \\ INSECTICIDAS
}

\author{
ROSINEIDE DA SILVA LOPES ${ }^{*}{ }^{*}$, LUCIANA GONÇALVES DE OLIVEIRA ${ }^{1}$, GEIZIQUELE DE LIMA ${ }^{2}$, MARIA \\ TEREZA dOS SANTOS CORREIA ${ }^{3}$, ANTONio FÉlix dA COSTA ${ }^{1}$, Elza Áurea DE LUNA-ALVES LIMA ${ }^{4}$, \\ VERA LÚCIA DE MENEZES LIMA ${ }^{3}$

\footnotetext{
${ }^{1}$ Agronomic Institute of Pernambuco. Av General San Martin, $n^{\circ}$ 1371, Bongi, Recife, PE 50761-000, Brazil. <rs.lopes@hotmail.com>; <lugoliveira@yahoo.com.br>; <afelixc.ipa@gmail.com>

${ }^{2}$ Institute of Natural, Human and Social Sciences, Federal University of Mato Grosso, Av. Alexandre Ferronato, ${ }^{\circ} 1200$, Setor Industrial, Snop, MT, 78557-267, Brazil. <geize.lma@gmail.com> 420, Recife, PE, Brazil. <mtscorreia@gmail.com>; <vlml@ufpe.br>

${ }^{4}$ Department of Mycology, Federal University of Pernambuco. Cidade Universitária, Recife, PE 50670-901, Brazil. <elza.aurea@gmail.com>

*Autor de correspondencia: <rs.lopes@hotmail.com>
} \\ ${ }^{3}$ Department of Biochemistry, Federal University of Pernambuco, Av. Prof. Morais Rego, S/N, Cidade Universitária, CEP 50670-
}

Recibido: 12/03/2018; aceptado: 24/10/2019; publicado en línea: 04/11/2019 Editor responsable: Magdalena Cruz

Lopes, R. S., Oliveira, L. G., Lima, G., Correia, M. T. S., Costa, A. F., Luna-Alves Lima, E. A., Lima, V. L. M. (2019) Pathogenic activity of Isaria spp. for control of Dactylopius opuntiae (Hemiptera: Dactylopiideae) and the effects of selected insecticides. Acta Zoológica Mexicana (nueva serie), 35, 1-5. https://doi.org/10.21829/azm.2019.3502249

ABSTRACT. We analyzed the activity of the entomopathogenic fungi Isaria farinosa, I. fumosorosea and I. javanica against the cochineal Dactylopius opuntiae, as well as the effects of the insecticides clorpirifos, acetamiprid, thiamethoxam and lambda-cyhalothrin on the conidia germination, mycelium growth and a sporulation of the fungi. These fungi were not pathogenic to cochineal. This the first report of the efficiency of Isaria spp. against this the insect. The bioassays of the compatibility of the insecticides acetamiprid and thiametoxam with species of Isaria indicate the possibility of the joint use of these products in studies on the control of D. opuntiae.

Key words: Biological control; cochineal; entomopathogenic fungi; insecticide

Lopes, R. S., Oliveira, L. G., Lima, G., Correia, M. T. S., Costa, A. F., Luna-Alves Lima, E. A., Lima, V. L. M. (2019) Acción patogénica de Isaria spp., para el control de Dactylopius opuntiae (Hemiptera: Dactylopiideae) y los efectos de algunos insecticidas. Acta Zoológica Mexicana (nueva serie), 35, 1-5. https://doi.org/10.21829/azm.2019.3502249 
RESUMEN. El trabajo analizó las acciones de los hongos entomopatógenos Isaria farinosa, I. fumosorosea y I. javanica contra la cochonilla Dactylopius opuntiae, así como el efecto de los insecticidas clorpirifos, acetamiprid, tiametoxam y lambda-cialotrina sobre la germinación, el crecimiento micelial y esporulación del mismo. Los hongos no fueron patógenos a D. opuntiae, siendo éste el primer reporte de la eficiencia de Isaria spp., sobre este insecto. Los bioensayos de la compatibilidad de los insecticidas acetamiprid y thiametoxam con especies de Isaria indican la posibilidad de uso conjunto de estos productos en estudios para el control de D. opuntiae.

Palabras clave: Control biológico; cochinilla-del-carmín; hongo entomopatógeno; insecticida

The cochineal scale insect, Dactylopius opuntiae (Cockerell) (Hemiptera: Dactylopiideae) is an insect used in countries such as Peru, the Canary Islands, and Mexico to produce the natural food coloring carmine. It has also been used as a biological control agent against invasive cactus species in South Africa. In Brazil and Mexico, this insect attacks crops of Opuntia ficus-indica (L.) cactus, causing severe loss of forage and fruit production, resulting in economic losses for farmers (Nobel, 2001; Paterson et al., 2011; Tiago et al., 2016).

The control of insect pests is often achieved using chemical products, which it used excessively can cause the contamination of the environment and harm to animal health. However, the use of entomopathogenic fungi can contribute to insect pest control (Alves, 1998; Avery et al., 2013). The genus Isaria comprises important pathogens that can be used to control insect pests. Isaria farinosa (Holm: Fries) Fries and Isaria fumosorosea (Wize) Brown \& Smith were efficient against the mealy bugs Rhizoecus kondonis Kuwana and Planococcus citri (Risso) (Zimmermann, 2008; Demirci et al., 2011). The combined application of entomopathogenic agents and insecticides can amplify the lethality of natural pathogens (Avery et al., 2013; Silva et al., 2015). This study analyze the potential of the I. farinosa, I. javanica, and $I$. fumosorosea in controlling D. opuntiae, and evaluated the effects of the insecticides chlorpyrifos, acetamiprid, thiamethoxam, and lambda-cyhalothrin on these fungi in terms of conidia germination, mycelium growth, and spore formation.

Isaria farinosa (URM5016 and URM5060) and I. javanica (URM4993 and URM4995) were obtained from the URM Culture Collection (WDCM604) of Federal University of Pernambuco (UFPE); $I$. farinosa (ESALQ1205 and ESALQ1355) and I. fumosorosea (ESALQ1296 and ESALQ1297) were obtained from the ESALQ Collection of Microorganisms - ESALQ of the University of São Paulo (USP). The strains were cultivated in Sabouraud Agar Medium (SAD) for 12 days, and then suspensions $\left(1 \times 10^{8}\right.$ conidia/mL) were made in $10 \mathrm{ml}$ of Tween $80(0.1 \%)$ solution.

The cochineal was collected in $O$. ficus-indica plantations, and the insects were raised in culture chambers at $28 \pm 1{ }^{\circ} \mathrm{C}$, on healthy cactus cladodes. The experiments were performed with three replicates and consisted of nine treatments (eight strains and one control), totaling 150 females and 150 nymphs per treatment. The cactus cladodes infested with nymphs second instar and adult females were sprayed with 10 $\mathrm{mL}$ of $1 \times 10^{8}$ conidia/mL of each strain, and for control with Tween $80(0.1 \%)$ solution using a manual sprayer. The cladodes were placed on rectangular plastic trays $(30 \times 15 \times 8 \mathrm{~cm})$ and maintained at $26 \pm 1^{\circ} \mathrm{C}$, for 10 days; after which 50 adult females and 50 nymphs were collected from each cladode. Confirmation of insect mortality was observed after fungal sporulation by the fungal infection according to Alves (1998).

The chemical insecticides chlorpyrifos, acetamiprid, thiamethoxam and lambda-cyhalothrin were tested at three different concentrations based on the recommendations of the manufacturers, with the median concentration (CMed) corresponding to that recommended for field use; the minimum concentrations (CMed/2) and maximum concentrations (CMedx2) (Table 1), according to (Lopes et al., 2018). To evaluate the germination, $0.1 \mathrm{~mL}$ of each suspensions with $1 \times 10^{8}$ conidia/mL in Tween $80(0.1 \%)$ solution + 
insecticide were mixed and after one hour, were inoculated into Petri dishes containing SDA and incubated $\left(26 \pm 1{ }^{\circ} \mathrm{C} ; 80 \pm 10 \% \mathrm{RH}\right)$; the control was the fungal suspension without the insecticide. The germination percentage was determined after 16 hours, counting 500 conidia, between germinated and non-germinated by plates, and then the results were given in the formula $\mathrm{G}=\mathrm{N} \times 100 / 500$, where $\mathrm{N}$ is germinated spore according to Alves and Pereira (1998). To evaluate mycelial growth, a filter paper disc (0.3 mm diameter) was soaked with $0.01 \mathrm{~mL}$ of $1 \times 10^{8}$ conidia/mL in a Petri dish with SDA + insecticides (as well as control plates without pesticide), and incubated $\left(26 \pm 1^{\circ} \mathrm{C} ; 80 \pm 10 \% \mathrm{RH}\right)$ for 12 days. The mycelial growth was determined by measuring the diameter of each colony. To analyze sporulation, colony fragments were transferred to test tubes containing $10 \mathrm{~mL}$ of Tween $80(0.1 \%)$ solution, and the number of spores in each suspension was counted. Statistical analyses of the data were performed by analysis of variance (ANOVA) and the means compared using the Tukey test at a 5\% probability (SAS Institute, 1999-2001).

Table 1. Chemical pesticides utilized for controlling cochineal (order Hemiptera). Font: Lopes et al. (2018)

\begin{tabular}{|c|c|c|c|c|c|c|}
\hline \multirow{2}{*}{ Product's name } & \multirow{2}{*}{$\begin{array}{c}\text { Type of } \\
\text { formulation }\end{array}$} & \multirow{2}{*}{ Chemical Type } & \multirow{2}{*}{$\begin{array}{l}\text { Constituent } \\
\text { Active }\end{array}$} & \multicolumn{3}{|c|}{$\begin{array}{c}\text { Concentration recommended by the } \\
\text { manufacturer }(\mathrm{L})\end{array}$} \\
\hline & & & & Minimum & Median & Maximum \\
\hline Lorsban $480 \mathrm{BR}$ & $\begin{array}{l}\text { Emulsifiable } \\
\text { concentrate }\end{array}$ & Organophosphate & Chlorpyrifos & $0.75 \mathrm{~mL} / \mathrm{L}$ & $1.5 \mathrm{~mL} / \mathrm{L}$ & $3.0 \mathrm{~mL} / \mathrm{L}$ \\
\hline Mospilan & Soluble powder & Neonicotinoid & Acetamiprid & $0.125 \mathrm{~g} / \mathrm{L}$ & $0.25 \mathrm{~g} / \mathrm{L}$ & $0.5 \mathrm{~g} / \mathrm{L}$ \\
\hline Actara $250 \mathrm{WG}$ & Dispersible granules & Neonicotinoid & Thiamethoxam & $0.10 \mathrm{~g} / \mathrm{L}$ & $0.20 \mathrm{~g} / \mathrm{L}$ & $0.40 \mathrm{~g} / \mathrm{L}$ \\
\hline $\begin{array}{l}\text { Karatê ZEON } \\
250 \mathrm{CS}\end{array}$ & $\begin{array}{l}\text { Encapsulated } \\
\text { suspension }\end{array}$ & Pyrethroid & $\begin{array}{l}\text { Lambda- } \\
\text { cyhalothrin }\end{array}$ & $0.50 \mathrm{~mL} / \mathrm{L}$ & $1.0 \mathrm{~mL} / \mathrm{L}$ & $2.0 \mathrm{~mL} / \mathrm{L}$ \\
\hline
\end{tabular}

Isaria species did not cause efficient mortality averages on the cochineal. Isaria javanica URM4995 and I. farinosa ESALQ1355 caused only 14 and 16\% mortality of the nymphs, compared to 5\% mortality in the control ( $p=0.05$ ) (Table 2). Isaria farinosa ESALQ1205 and I. javanica URM4993 caused the death of 6 and $7 \%$ of $D$. opuntiae nymphs, respectively, while the other strains did not cause nymph mortality (Table 2). None of the Isaria strains caused adult female mortality. This is the first study to report on the pathogenicity of Isaria spp. on D. opuntiae. Dactylopius have protective layers of fatty and waxy substances covering their bodies that repel aqueous solutions (Nobel, 2001; Demirci et al., 2011). This waxy barrier probably impedes the contact of fungal conidia with the insects' tegument, thus stifling fungal germination. The association of entomopathogens with adjuvants (such as oils, plant extracts, and/or insecticides) could represent viable options for increasing the prevalence of infection with fungal pathogens in this insect (Silva et al., 2015).

Table 2. Mean percentage of mortality $( \pm \mathrm{SD})$ of the nymphs of Dactylopius opuntiae when treated with different strains of Isaria. Means followed by the same letters do not differ significantly at a 5\% probability level the Tukey Test.

\begin{tabular}{cc}
\hline Strains & Mortality (\%) \\
\hline Control & $5.00 \pm 2.37 \mathrm{bc}$ \\
Isaria farinosa ESALQ1205 & $6.00 \pm 0.94 \mathrm{bc}$ \\
Isaria farinosa ESALQ1355 & $16.00 \pm 1.09 \mathrm{a}$ \\
Isaria farinosa URM5016 & $0.00 \pm 0.00 \mathrm{c}$ \\
Isaria farinosa URM5060 & $0.00 \pm 0.00 \mathrm{c}$ \\
Isaria javanica URM4995 & $14.00 \pm 0.94 \mathrm{a}$ \\
Isaria javanica URM4993 & $7.00 \pm 1.44 \mathrm{~b}$ \\
Isaria fumosorosea ESALQ1296 & $0.00 \pm 0.00 \mathrm{c}$ \\
Isaria fumosorosea ESALQ1297 & $0.00 \pm 0.00 \mathrm{c}$ \\
\hline Coefficient of Variation (\%) & 17.28 \\
\hline
\end{tabular}


The insecticides chlorpyrifos and lambda-cyhalothrin inhibited conidia germination, mycelium growth and a sporulation, principally when used at the maximum concentrations (Table 3). Asi et al. (2010), verified that 13 insecticides significantly inhibited the germination and mycelial growth of $M$. anisopliae and I. fumosorosea, with chlorpyrifos being the most toxic in insecticide. Avery et al. (2013), observed that the adjuvant oils significantly inhibited germination and mycelial growth of I. fumosorosea. The insecticides thiamethoxam and acetamiprid caused no negative effects on conidia germination, mycelium growth, or sporulation of the strains $(p=0.05)$, although the maximum concentrations of the insecticides tested were detrimental to I. fumosorosea ESALQ1297 (Table 3); those insecticides can therefore be considered for combined applications. Similar results were reported by Amjad et al. (2012), who found that acetamiprid inhibited germination in I. fumosorosea only at the highest concentration tested, having no effect at lower concentrations. Entomopathogenic fungi and selective insecticides can act synergistically, reducing the of insecticide dosages, which contributes to the preservation of natural enemies and, may reduce the environmental pollution and the appearance of resistant insects (Silva et al., 2015).

Table 3. Effects of different pesticides on the germination $(\%)$, growth $(\mathrm{cm})$ and sporulation $\left(10^{7} \mathrm{conidia} / \mathrm{mL}\right)$ of Isaria species. Means followed by the same letters do not differ significantly at a 5\% probability level (Tukey test).

\begin{tabular}{|c|c|c|c|c|c|c|c|c|c|}
\hline \multirow{2}{*}{$\begin{array}{l}\text { Insecticide/ } \\
\text { Concentration }\end{array}$} & \multicolumn{3}{|c|}{ Isaria farinosa ESALQ1355 } & \multicolumn{3}{|c|}{ Isaria javanica URM4995 } & \multicolumn{3}{|c|}{ Isaria fumosorosea ESALQ1297 } \\
\hline & Germination & Growth & Sporulation & Germination & Growth & Sporulation & Germination & Growth & Sporulation \\
\hline \multicolumn{10}{|l|}{ Chlorpyrifos } \\
\hline Control & $99 \pm 0.46 \mathrm{a}$ & $4.00 \pm 0.27 \mathrm{a}$ & $8.00 \pm 1.04 \mathrm{a}$ & $99 \pm 0.00 \mathrm{a}$ & $3.00 \pm 0.10 \mathrm{a}$ & $2.00 \pm 0.1 \mathrm{a}$ & $99 \pm 0.26 \mathrm{a}$ & $3.40 \pm 0.0 \mathrm{a}$ & $3.00 \pm 0.0 \mathrm{a}$ \\
\hline Minimum $(0.75 \mathrm{~mL} / \mathrm{L})$ & $55 \pm 3.23 b$ & $1.40 \pm 0.01 \mathrm{~b}$ & $1.90 \pm 0.33 b$ & $84 \pm 0.26 b$ & $1.70 \pm 0.04 b$ & $0.90 \pm 0.3 \mathrm{ab}$ & $87 \pm 2.78 b$ & $1.20 \pm 0.0 \mathrm{bc}$ & $1.20 \pm 0.0 \mathrm{~b}$ \\
\hline Median (1.5 mL/L) & $29 \pm 5.81 c$ & $0.70 \pm 0.10 \mathrm{c}$ & $0.70 \pm 0.03 \mathrm{c}$ & $83 \pm 1.62 b$ & $1.20 \mathrm{~b} \pm 0.07 \mathrm{~b}$ & $0.60 \pm 0.04 \mathrm{~b}$ & $87 \pm 0.70 b$ & $0.00 \pm 0.00 \mathrm{c}$ & $0.00 \pm 0.0 \mathrm{~b}$ \\
\hline Maximum $(3.0 \mathrm{~mL} / \mathrm{L})$ & $0.00 \pm 0.00 \mathrm{~d}$ & $0.00 \pm 0.00 \mathrm{~d}$ & $0.00 \pm 0.00 \mathrm{c}$ & $63 \pm 4.66 c$ & $0.50 \pm 0.00 \mathrm{c}$ & $0.40 \pm 0.06 \mathrm{~b}$ & $51 \pm 2.80 \mathrm{~b}$ & $0.00 \pm 00 \mathrm{c}$ & $0.00 \pm 0.0 \mathrm{~b}$ \\
\hline \multicolumn{10}{|l|}{ Acetamiprid } \\
\hline Control & $99 \pm 0.53 a$ & $3.60 \pm 0.00 \mathrm{a}$ & $6.30 \pm 0.60 \mathrm{a}$ & $99 \pm 0.80 \mathrm{a}$ & $3.20 \pm 0.00 \mathrm{a}$ & $1.60 \pm 0.00 \mathrm{a}$ & $99 \pm 1.4 \mathrm{a}$ & $3.40 \pm 0.06 \mathrm{a}$ & $3.00 \pm 0.80 \mathrm{a}$ \\
\hline Minimum $(0.12$ & $98 \pm 1.16 \mathrm{a}$ & $3.5 \pm 0.00 \mathrm{a}$ & $5.90 \pm 0.21 \mathrm{a}$ & $94 \pm 1.92 \mathrm{a}$ & $20 \pm 0.15 \mathrm{a}$ & $1.80 \pm 0.13 \mathrm{a}$ & $92 \pm 0.8 \mathrm{a}$ & $3.20 \pm 0.08 \mathrm{ab}$ & $.20 \mathrm{a}$ \\
\hline Median $(0.25 \mathrm{~mL} / \mathrm{L})$ & $96 \pm 0.46 a$ & $3.5 \pm 0.02 \mathrm{a}$ & $4.30 \pm 0.03 \mathrm{a}$ & $92 \pm 1.33 \mathrm{a}$ & $2.80 \pm 0.02 \mathrm{a}$ & $1.50 \pm 0.59 \mathrm{a}$ & $90 \pm 2.4 \mathrm{a}$ & $3.00 \pm 0.03 \mathrm{ab}$ & $2.70 \pm 0.03 \mathrm{a}$ \\
\hline Maximum $(0.5 \mathrm{~mL} / \mathrm{L})$ & $95 \pm 0.26 \mathrm{a}$ & $2.80 \pm 0.06 \mathrm{a}$ & $3.60 \pm 0.07 \mathrm{~b}$ & $91 \pm 1.41 \mathrm{a}$ & $2.70 \pm 0.07 \mathrm{a}$ & $0.90 \pm 0.15 b$ & $75 \pm 11.6 b$ & $2.70 \pm 0.01 \mathrm{~b}$ & $2.60 \pm 0.38 \mathrm{a}$ \\
\hline \multicolumn{10}{|l|}{ Thiamethoxam } \\
\hline Control & $96 \pm 0.53 a$ & $3.30 \pm 0.03 \mathrm{a}$ & $7.80 \pm 0.34 \mathrm{a}$ & $98 \pm 0.53 a$ & $3.60 \pm 0.06 \mathrm{a}$ & $2.80 \pm 0.04 \mathrm{a}$ & $99 \pm 0.2 \mathrm{a}$ & $3.70 \pm 0.02 \mathrm{a}$ & $3.00 \pm 0.19 \mathrm{a}$ \\
\hline Minimum (0.1 & $94 \pm 0.96 a$ & $3.30 \pm 0.07 \mathrm{a}$ & $7.30 \pm 0.38 \mathrm{a}$ & $97 \pm 0.26 \mathrm{a}$ & $3.30 \pm 0.04 \mathrm{a}$ & $2.70 \pm 0.25 \mathrm{a}$ & $98 \pm 0.5 \mathrm{a}$ & $3.40 \pm 0.04 \mathrm{ab}$ & $2.30 \pm 0.15 \mathrm{ab}$ \\
\hline Median $(0.20 \mathrm{~mL} / \mathrm{L})$ & $93 \pm 0.46 a$ & $3.20 \pm 0.08 \mathrm{a}$ & $6.20 \pm 0.40 \mathrm{a}$ & $96 \pm 0.00 \mathrm{a}$ & $3.20 \pm 0.10 \mathrm{a}$ & $2.50 \pm 0.21 \mathrm{a}$ & $98 \pm 0.8 \mathrm{a}$ & $3.30 \pm 0.06 \mathrm{ab}$ & $2.20 \pm 0.16 \mathrm{ab}$ \\
\hline Maximum $(0.5 \mathrm{~mL} / \mathrm{L})$ & $92 \pm 1.48 \mathrm{a}$ & $3.20 \pm 0.07 \mathrm{a}$ & $5.40 \pm 0.60 \mathrm{a}$ & $96 \pm 0.53 a$ & $3.00 \pm 0.03 \mathrm{a}$ & $1.80 \pm 0.14 \mathrm{ab}$ & $98 \pm 0.4 \mathrm{a}$ & $3.00 \pm 0.01 \mathrm{~b}$ & $1.50 \pm 0.02 b$ \\
\hline \multicolumn{10}{|l|}{ Lambda-cyhalothrin } \\
\hline Control & $99 \pm 0.26 \mathrm{a}$ & $3.30 \pm 0.03 \mathrm{a}$ & $7.30 \pm 0.34 \mathrm{a}$ & $99 \pm 1.4 \mathrm{a}$ & $3.50 \pm 0.18 \mathrm{a}$ & $2.80 \pm 0.44 \mathrm{a}$ & $99 \pm 0.5 \mathrm{a}$ & $3.40 \pm 0.03 \mathrm{a}$ & $1.30 \pm 0.14 \mathrm{a}$ \\
\hline Minimum $(0.5$ & $86 \pm 1.22 b$ & $2.00 \pm 0.01 \mathrm{~b}$ & $4.30 \pm 0.15 b$ & $87 \pm 0.5 b$ & $3.00 \pm 0.10 \mathrm{ab}$ & $2.30 \pm 0.21 \mathrm{ab}$ & $86 \pm 5.2 b$ & $3.40 \pm 0.05 \mathrm{a}$ & $0.800 \pm 0.04 \mathrm{~b}$ \\
\hline Median $(1.0 \mathrm{~mL} / \mathrm{L})$ & $86 \pm 0.02 b$ & $1.90 \pm 0.11 b$ & $3.10 \pm 0.17 b c$ & $86 \pm 1.0 \mathrm{~b}$ & $2.80 \pm 1.12 \mathrm{ab}$ & $1.80 \pm 0.11 \mathrm{ab}$ & $85 \pm 0.2 b$ & $3.30 \pm 0.08 \mathrm{a}$ & $0.80 \pm 0.11 b$ \\
\hline $\operatorname{Maximum}(2.0 \mathrm{~mL} / \mathrm{L})$ & $80 \pm 1.86 b$ & $2.30 \pm 0.08 \mathrm{~b}$ & $2.00 \pm 0.52 \mathrm{c}$ & $80 \pm 1.0 \mathrm{~b}$ & $2.70 \pm 0.06 \mathrm{~b}$ & $1.50 \pm 0.06 \mathrm{~b}$ & $75 \pm 3.3 b$ & $2.20 \pm 0.08 \mathrm{~b}$ & $0.00 \pm 0.02 \mathrm{c}$ \\
\hline
\end{tabular}

Our results indicate that the species of Isaria were not pathogenic to adult females and nymphs of D. opuntiae. Additionally, the insecticides thiamethoxam and acetamiprid demonstrated compatibility with all the Isaria fungal strains tested, suggesting that their use in mixtures could enhance the effectiveness of Isaria in the control of insect pests.

AKNOWLEDGements. We thank the "Fundação de Amparo à Ciência e Tecnologia do Estado de Pernambuco" (FACEPE), National Council for Scientific and Technological Development (CNPq), Coordination for the Improvement of Higher Level -or Education- Personnel (CAPES) and "Banco do Nordeste" (BNB).

\section{LITERATURE CITED}

Alves, S. B. (1998) Fungos Entomopatogênicos. Pp. 289-370. In: S. B. Alves (Ed.). Controle Microbiana de Insetos. Fundação de Estudos Agrários Luiz de Queiroz (FEALQ), Piracicaba. 
Alves, S. B., Pereira, R. (1998) Produção de fungos entomopatogênicos. Pp. 845-867. In: S. B. Alves (Ed.). Controle Microbiano de Insetos. Fundação de Estudos Agrários Luiz de Queiroz (FEALQ), Piracicaba.

Amjad, M., Bashir, M. H., Afzal, M., Sabri, M. A., Javed, N. (2012) Effects of commercial pesticides against cotton whitefly (Bemisia tabaci Genn.) and mites (Tetranychus urticae Koch) on growth and conidial germination of two species of entomopathogenic fungi. Pakistan Journal of Life and Social Sciences, 10, 22-27. http://www.pjlss.edu.pk/pdf_files/2012_1/22-27.pdf

Asi, M. R., Bashir, M. H., Afzal, M., Ashfaq, M., Sahi, S. (2010) Compatibility of entomopathogenic fungi, Metarhizium anisopliae and Paecilomyces fumosoroseus with selective insecticides. Pakistan Journal of Botany, 42, 4207-4214. http://www.pakbs.org/pjbot/PDFs/42\%286\%29/PJB42\%286\%294207.pdf

Avery, P. B., Pick, D. A., Aristizábal, L. F., Kerrigan, J., Powell, C. A., Rogers, M. E., Arthurs, S. P. (2013) Compatibility of Isaria fumosorosea (Hypocreales: Cordycipitaceae) blastospores with agricultural chemicals used for management of the Asian Citrus Psyllid, Diaphorina citri (Hemiptera: Liviidae). Insects, 4, 694-711. http://doi.org/10.3390/insects4040694

Demirci, F., Mustu, M., Kaydan, M. B., Ulgentur, S. (2011) Laboratory evaluation of the effectiveness of the entomopathogen, Isaria farinosa, on citrus mealybug, Planococcus citri. Journal of Pest Science, 84, 337-342. https://doi.org/10.1007/s10340-011-0350-9

Lopes, R. S., Oliveira, L. G., Costa, A. F., Correia, M. T., Luna-Alves Lima, E. A., Lima, V. L. M. (2018) Efficacy of Libidibia ferrea var. ferrea and Agave sisalana extracts against Dactylopius opuntiae (Hemiptera: Coccoidea). Journal of Agricultural Science, 10, 255-267. https://doi.org/10.5539/jas.v10n4p255

Nobel, P. S. (2001) Ecophysiology of Opuntia ficus-indica. Pp 13-20. In: C. Mondragón-Jacobo, S. PérezGonzález (Eds.). Cactus (Opuntia spp.) as forage. Food and Agriculture. Organization of the United Nations (FAO) - Plant production and protection paper, Rome. http://www.fao.org/docrep/005/Y2808E/y2808e06.htm

Paterson, I. D., Hoffmann, J. H., Klein, H., Mathenge, C. W., Neser, S., Zimmermann, H. G. (2011) Biological control of Cactaceae in South Africa. African Entomology, 19, 230-246. https://doi.org/10.4001/003.019.0221

SAS Institute (1999-2001) SAS user's guide: Statistics. SAS Institute. Cary, North Carolina.

Silva, A. P. A. P., Alves, R. T., Lima, E. A. L. A., Lima, V. L. M. (2015) Bioformulations in pest control - A Review. Annual Research \& Review in Biology, 5, 535-543. https://doi.org/10.9734/ARRB/2015/12395

Tiago, P. V., Medeiros, L. V., Leão, M. P. C., Santos, A. C. S., Costa, A. F., Oliveira, N. T. (2016) Polymorphisms in entomopathogenic fusaria based on inter simple sequence repeats (ISSR). Biocontrol Science and Technology, 10, 1401-1410. https://doi.org/10.1080/09583157.2016.1210084

Zimmermann, G. (2008) The entomopathogenic fungi Isaria farinosa (formerly Paecilomyces farinosus) and the Isaria fumosorosea species complex (formerly Paecilomyces fumosoroseus): biology, ecology and use in biological control. Biocontrol Science and Technology, 18, 865-890. http://doi.org/10.1080/09583150802471812 